\title{
Teotihuacan, an exceptional corporate society of
} Mesoamerica

Linda R. Manzanilla

\section{OpenEdition}

Electronic version

URL: https://journals.openedition.org/annuaire-cdf/16409

DOI: 10.4000/annuaire-cdf.16409

ISBN: 978-2-7226-0572-5

ISSN: 2109-9227

Publisher

Collège de France

Printed version

Date of publication: 30 December 2020

Number of pages: $702-703$

ISBN: 978-2-7226-0516-9

ISSN: 0069-5580

\section{Electronic reference}

Linda R. Manzanilla, "Teotihuacan, an exceptional corporate society of Mesoamerica", L'annuaire du Collège de France [Online], 118 | 2020, Online since 01 April 2021, connection on 22 August 2022. URL: http://journals.openedition.org/annuaire-cdf/16409 ; DOI: https://doi.org/10.4000/annuaire-cdf.16409 


\title{
TEOTIHUACAN, AN EXCEPTIONAL CORPORATE SOCIETY OF MESOAMERICA
}

\author{
Linda R. MANZANILLA \\ Professeure à l'Université nationale autonome du Mexique \\ et membre du Collège national de Mexico
}

Mots-clés : Teotihuacan, Mesoamerica

Conférence prononcée le 27 juin 2018 (invitation sur proposition du Pr Philippe Descola).

This talk will review what I believe are the exceptional characteristics of the city of Teotihuacan in Mesoamerica of the Classic period: a huge planned settlement with an urban grid, a multiethnic society, a corporate organization. Teotihuacan, in Central Mexico, stands out as one of the largest pre-industrial urban sites, with characteristics that set this site apart as an exception in Mesoamerica.

One of these characteristics is life in multifamily apartment compounds. Through my thorough excavation of Oztoyahualco 15B:N6W3, a peripheral apartment compound, my team and I could unveil life in the city; each household had an apartment with a kitchen, a storeroom, dormitories, porticoes to work, service courtyards, and ritual courtyards. The households living inside a compound shared a common activity: they were corporate groups.

These apartment compounds were set around neighborhood centers that not only coordinated life in the neighborhood, promoting weekly markets, feasts and communal rituals, but also organized caravans through ally sites to bring to the city sumptuary goods as well as specialized foreign craftsmen. We have counted 22 of such neighborhoods, which constitute the most dynamic part of Teotihuacan society, as they were competing to bring the most lavish and exotic goods to the city. My extensive excavations at the neighborhood center of Teopancazco has unveiled the anatomy of a multiethnic compound that fostered caravans to the Gulf Coast of Mexico, particularly to Nautla in Veracruz, to bring 14 varieties of marine fish, crabs, crocodiles, coastal herons, cotton cloths, volcanic glass from the site of Altotonga in Veracruz, and also craftsmen from different sites in the corridor.

Four scales of craft production may be detected:

1) Embedded craftsmen in palatial structures, such as Xalla, the scenario of the ruling elite, particularly lapidary workers (specially working with mica from Oaxaca).

2) Multiethnic craftsmen embedded in neighborhood centers such as Teopancazco, in southeastern Teotihuacan, particularly involved in manufacturing very complex attires and headdresses for the intermediate elite managing the neighborhood. Many involve foreign raw materials. 
3) Diverse craftsmen settled in the periphery of the city, producing all the implements and objects consumed by the urban population: pottery, obsidian implements, grinding stones; small adornments of slate, shell, greenstone, as well as stucco to plaster walls, floors, streets, and plazas.

4) Small-scale production in the domestic apartment compounds for household consumption.

It is possible that the 125,000 inhabitants of the city had a ruling council. There are no traces of single rulers. Such a heterogeneous population could avoid coups d'état through the participation of elite from the four districts of the city. My extensive excavations in the palatial complex of Xalla have given us elements to propose a co-rulership for the city, co-rulers that were personifying deities.

The contradiction between the corporate aspects of this society at the base and at the summit, and the competing and enriching character of the intermediate elite heading the neighborhoods provoked a revolt of these last towards the co-rulership, when the Teotihuacan state tried to control these semi-autonomous social units. The core of the city was burned by AD 550 . 